\title{
Long-term effects of rotational atherectomy in patients with heavy calcified coronary artery lesions: a single-centre experience
}

\author{
Stanisław Bartuś $\hat{s}^{1,2}$, Rafał Januszek ${ }^{1}$, Jacek Legutko ${ }^{1,2}$, Łukasz Rzeszutko', \\ Artur Dziewierz ${ }^{1,2}$, Dariusz Dudek ${ }^{1,2,3}$ \\ $12^{\text {nd }}$ Department of Cardiology and Cardiovascular Interventions, University Hospital, Krakow, Poland \\ ${ }^{2} 2^{\text {nd }}$ Department of Cardiology, Jagiellonian University Medical College, Krakow, Poland \\ ${ }^{3}$ Department of Interventional Cardiology, Jagiellonian University Medical College, Krakow, Poland
}

\begin{abstract}
A b stract
Background: Rotational atherectomy (RA) plays a significant role in contemporary percutaneous coronary interventions ( $\mathrm{PCl}$ ), especially in the era of population aging and expansion of $\mathrm{PCl}$ indications.

Aim: The aim of the current study was to evaluate the rate of periprocedural complications, the long-term effectiveness of RA, and potential factors influencing the incidence of major adverse cardiac events (MACE) and major cardiac as well as cerebrovascular events (MACCE) after RA.

Methods: The study included 60 consecutive patients who underwent effective RA between January 2002 and May 2016. Patients were followed-up for 2,616 days for MACE and MACCE.

Results: The mean age of the enrolled patients was 72.1 years, and $78.3 \%$ were males. The mean follow-up period lasted $835.3 \pm 611.8$ days. Periprocedural complications occurred in $12(20.0 \%)$ patients. In the follow-up of up to 2,616 days, 64\% of patients were free of MACCE and $68 \%$ were free of MACE. Univariate Cox analysis revealed that MACCE occurred more often in patients from the high-risk group based on the EuroSCORE II and those with longer lengths of the implanted stent(s) after the RA procedure. In multivariate Cox regression analysis, both high-risk category and mean stent(s) length were identified as independent predictors of MACCE. EuroSCORE II was confirmed to be the only independent predictor of MACE after RA. Conclusions: Rotational atherectomy is a safe and sufficient technique for the endovascular treatment of heavily calcified coronary artery lesions. Individuals at a higher risk as assessed by the EuroSCORE II before RA and those with longer stent(s) implanted after RA are predisposed to MACCE in the follow-up.
\end{abstract}

Key words: rotational atherectomy, complications, effectiveness, major adverse cardiac and cerebrovascular events

Kardiol Pol 2017; 75, 6: 564-572

\section{INTRODUCTION}

Next year will mark the $30^{\text {th }}$ anniversary since Jerome Ritchie, David Auth and colleagues introduced rotational atherectomy (RA) as a technique for endovascular treatment [1]. $\mathrm{RA}$, alongside orbital atherectomy (OA) and excimer laser (EL) atherectomy, belongs to the world's leading techniques used for the atherectomy of calcified coronary artery lesion (CCAL). Recent estimates indicate that the current frequency of RA use has trended downward in the last several years, especially in low-volume centres. In European countries, the rate of RA ranges from $0.8 \%$ to $3.1 \%$ of all percutaneous coronary interventions (PCls) [2]. The crucial advantage of RA over regular $\mathrm{PCl}$ is the enlargement of the artery lumen by physical removal of plaque and reduction in plaque rigidity, which enables easier dilation of the artery. Vascular stiffness is mainly determined by coronary artery calcification (CAC). The core of the RA device is a diamond-encrusted elliptical burr, which is rotated at high speeds. The procedural success of RA with subsequent coronary stenting reaches more than $90 \%$ [3]. In the past, when balloon angioplasty and stents were 
used to treat severe CCALs, the major adverse cardiac event (MACE) rate ranged from $11 \%$ to $15.8 \%$ at 15 months [4]. The rate of MACE in patients after RA and coronary stenting with drug-eluting stent (DES) was lower in comparison to the MACE rates reported in DES alone PCls trials that have assessed the PCl of moderate and severely calcified lesions [5]. Recently published intermediate and long-term outcomes after $\mathrm{PCl}$ and DES with adjunctive RA report rates of target lesion revascularisation (TLR) $<10 \%$ within one to two years [6]. In patients treated with RA, rates of MACE are lower with DES stenting compared with bare-metal stent (BMS) stenting $[6,7]$. However, the ROTAXUS study did not demonstrate the advantage of RA with DES implantation over angioplasty with DES alone [8]. The number of published studies with long-term follow-ups is small and limited to randomised controlled trials. Therefore, smaller single-centre studies with long-term follow-ups may bring additional insight into the effectiveness of RA in patients with CCAs.

The aim of this study was to assess the effectiveness, periprocedural complications, and long-term effects of RA in terms of MACEs and major adverse cardiac and cerebrovascular events (MACCEs) in patients with heavy CCAs.

\section{METHODS}

Data on 60 consecutive patients who underwent effective RA in our centre between January 2002 and May 2016 were collected, retrospectively. However, most procedures were performed in the past five years (55 rotablations; $91.6 \%$ ). The maximum follow-up time was 2,616 days. The patient evaluation was based on both clinical interview and an additional non-invasive evaluation of cardiac ischaemia when possible. The pre-procedure clinical risk was defined according to the additive EuroSCORE II and SYNTAX score calculator, and was defined as low risk $(\leq 2 \%)$, intermediate risk (3-5\%), and high risk $(\geq 6 \%)$, considering the EuroSCORE II and as low (0-22 points), intermediate (23-32 points), and high ( $\geq 33$ points) when considering the SYNTAX score.

A Rotablator (Boston Scientific, Marlborough, MA, USA) was used to perform RA. As recommended, patients with absolute contraindications to RA, i.e. saphenous vein graft lesions, thrombus, dissection, and occlusions through which a guidewire would not pass, were excluded. Relative contraindications including indication to bypass surgery (not possible to perform whether due to patient ineligibility or lack of on-site cardiac surgery), severe three-vessel or unprotected left main disease, severe left ventricular dysfunction, lesion length more than $25 \mathrm{~mm}$, and lesion angulation more than 45 degrees were assessed individually, and the final decision was made by the main operator of the procedure. All patients gave informed consent for the procedure. The study complies with the Declaration of Helsinki on the ethical principles for medical research involving human subjects.

\section{Primary study endpoints}

The study endpoints were the rates of MACE and MACCE defined as cardiac death, myocardial infarction (MI), the requirement of TLR for MACE, and cardiac death, MI, the requirement of TLR, and cerebral stroke for MACCE. Death was considered to be of cardiac origin unless obvious non-cardiac causes could be identified. TLR was defined as either $\mathrm{PCl}$ - plain old balloon angioplasty (POBA)/DES or coronary artery bypass grafting (CABG) performed to treat in-stent restenosis or stent thrombosis of the target lesion, including the proximal and distal edges of the stent.

\section{Secondary study endpoints}

The secondary endpoints included angiographic success defined as success in facilitating stent delivery with a residual stenosis $<50 \%$, without severe angiographic complications as well as the rate of individual severe angiographic complications during the procedure. Severe angiographic complications included severe dissections, perforation, persistent slow-flow, persistent no-reflow, and abrupt closure. Periprocedural complications included time from the procedure to the discharge of the patient.

\section{Statistical analysis}

The Kaplan-Meier analysis method was used for the primary endpoint assessment. Descriptive statistics are provided for secondary endpoints. The data are expressed as means with standard deviations (SD) and percentage distribution as appropriate. Both univariate and multivariate Cox proportional hazards model analyses for MACE and MACCE were performed. Statistical significance was accepted at a 0.05 level of probability. The statistical analyses were performed using Statistica 10.0 software (Dell Software, Inc., Round Rock, TX, USA).

\section{RESULTS}

Baseline clinical characteristics are presented in Table 1. In terms of risk stratification (EuroSCORE II), a total of $38.3 \%$ patients were in the low-risk group, $41.7 \%$ in the moderate-risk group, and $20 \%$ had a EuroSCORE $\geq 6 \%$. The mean SYNTAX score was $24.6 \pm 13.6$ points. A total of $43.3 \%$ of patients had a SYNTAX score < 22 points, $28.3 \%$ between 22 and 32 points, and $28.3 \%$ of patients had a SYNTAX score $\geq 33$ points. All patients were treated with dual antiplatelet therapy after RA. All patients received aspirin, and as the second antiplatelet agent, clopidogrel was prescribed for 54 patients, prasugrel or ticagrelor in five patients, and one patient was treated with ticlopidine. Other medical treatment was continued in accordance with the current cardiologic guidelines and existing comorbidities. The main direct indication for RA was the inability to push the balloon catheter through the stenosis (69.5\%). However, only in a few cases, 
Table 1. General patients' characteristics

\begin{tabular}{|lc|}
\hline Overall group & $n=60$ \\
Male/Female & $47 / 13$ \\
Age [years] & $72.2 \pm 9.5$ \\
Body mass index $\left[\mathrm{kg} / \mathrm{m}^{2}\right]$ & $28.8 \pm 5.3$ \\
EuroSCORE II [\%] & $6.5 \pm 13$ \\
GFR [mL/min] & $71.8 \pm 29.1$ \\
Left ventricular ejection fraction [\%] & $46.6 \pm 11.9$ \\
Past and current smokers & $47(78.3 \%)$ \\
Peripheral artery disease & $16(26.7 \%)$ \\
Previous MI & $41(68.3 \%)$ \\
Previous PCl & $42(70.0 \%)$ \\
Previous CABG & $11(18.3 \%)$ \\
Hypertension & $58(96.7 \%)$ \\
Diabetes & $30(50.0 \%)$ \\
Insulin therapy & $14(23.3 \%)$ \\
Dyslipidaemia & $57(95.0 \%)$ \\
Obesity & $16(26.7 \%)$ \\
COPD/bronchial asthma & $10(16.7 \%)$ \\
Atrial fibrillation & $18(30.0 \%)$ \\
Chronic kidney disease & $15(25.0 \%)$ \\
Cerebral stroke/TIA & $9(15.0 \%)$ \\
\hline
\end{tabular}

Values are expressed as mean \pm standard deviation and percentage distribution. CABG - coronary artery bypass grafting; COPD — chronic obstructive pulmonary disease; GFR - glomerular filtration rate; $\mathrm{MI}$ - myocardial infarction; $\mathrm{PCl}$ - percutaneous coronary intervention; TIA — transient ischaemic attack

an over-the-wire catheter was used for such attempts. For patients in whom an over-the-wire catheter was used to deliver the balloon catheter, the attempt to deliver balloon catheter was effective in $80 \%$ of cases. In $25.4 \%$ of patients, successful delivery of balloon catheter was achieved, while satisfactory dilatation of the calcified artery was not sufficient or impossible. The acceptable predilatation was not possible, despite the use of high-pressure and/or cutting balloons in nearly $40 \%$ of patients out of those with unsuccessful predilatation. Finally, despite considering satisfactory predilatation, stent delivery failed in $5.1 \%$ of cases. The type and number of arteries that were treated with RA are presented in Table 2. A Floppy Rotawire was used in $58.3 \%$ of cases, whereas an Extra Support Rotawire was used in $41.7 \%$ of cases. In patients in whom the operator decided that coronary arteries were tortuous, the first choice was Floppy Rotawire, while in the remaining cases, an Extra Support Rotawire was used. The RA was conducted with pecking movements at a speed of approx. 150,000 rotations per minute. Every time we ran RA, we performed a few pecking movements. This action was repeated until achieving effortless burr passage to the distal part of the artery. Usually, a dozen to several dozen pecking
Table 2. Localisation of atherosclerotic lesions (significant stenoses/occlusions) in coronary arteries

\begin{tabular}{|c|c|c|}
\hline Arteries subjected to $\mathrm{PCl}: \mathbf{n}$ & Location & Cases: $\mathbf{n}(\%)$ \\
\hline \multirow[t]{6}{*}{ Total number, 79} & RCA & $16(20.2 \%)$ \\
\hline & LMCA & $13(16.4 \%)$ \\
\hline & LAD & $26(32.9 \%)$ \\
\hline & $C x$ & $17(21.5 \%)$ \\
\hline & $\mathrm{Mg}$ & $3(3.8 \%)$ \\
\hline & $\mathrm{Dg}$ & $4(5 \%)$ \\
\hline \multicolumn{3}{|l|}{ The types of lesion } \\
\hline \multirow[t]{6}{*}{ Single artery/branch, 44 (73.3\%) } & RCA & $16(36.4 \%)$ \\
\hline & LMCA & $1(2.3 \%)$ \\
\hline & LAD & $14(31.8 \%)$ \\
\hline & $C x$ & $10(22.7 \%)$ \\
\hline & $\mathrm{Mg}$ & $2(4.5 \%)$ \\
\hline & $\mathrm{Dg}$ & $1(2.3 \%)$ \\
\hline \multirow[t]{5}{*}{ Two arteries/branches, 13 (21.7\%) } & LMCA-LAD & $7(53.8 \%)$ \\
\hline & LMCA-CX & $2(15.4 \%)$ \\
\hline & LAD-Dg & $2(15.4 \%)$ \\
\hline & $\mathrm{Dg}-\mathrm{Cx}$ & $1(7.7 \%)$ \\
\hline & LAD-CX & $1(7.7 \%)$ \\
\hline Three arteries/branches, 3 (5\%) & LMCA-LAD-CX & $3(100 \%)$ \\
\hline
\end{tabular}

Values are expressed as percentage distribution. Cx - circumflex artery; Dg — diagonal artery; LAD — left anterior descending artery; LMCA — left main coronary artery; Mg — marginal artery; $\mathrm{RCA}$ - right coronary artery

movements were sufficient to achieve the intended purpose. In three cases, $\mathrm{PCl}$ after RA was performed without stent implantation - POBA (5\%), and in another two patients, BMS was implanted (3.33\%), whereas other patients underwent DES placement. The mean stent length was $25.1 \pm 8.7 \mathrm{~mm}$ and the diameter was $3.1 \pm 0.4 \mathrm{~mm}$. Twenty-nine (48.3\%) patients underwent single-stent implantation, 21 (35\%) double-stent implantation, six (10\%) triple-stent implantation, and one $(1.7 \%)$ quadruple-stent implantation. The relationship between final maximum burr diameter, final maximum balloon diameter, and final maximum stent diameter is presented in Figure 1. The right common femoral artery was most often used for vascular access (72\%). The radial artery access was found in $18 \%$ of procedures and was featured in the most recent PCls. Elective operations accounted for the majority of procedures at $46.7 \%$, followed by urgent $28.3 \%$, emergency $21.7 \%$, and salvage procedures in $3.3 \%$. Stable angina was the most common clinical presentation in patients qualified for RA (46.7\%), followed by unstable angina (31.7\%), non-ST-segment elevation MI (NSTEMI) (18.3\%), and ST-segment elevation MI (STEMI) (3.3\%). The type of culprit lesion according to the ACC/AHA guidelines was $2 \mathrm{~B}$ in $21.7 \%$ 


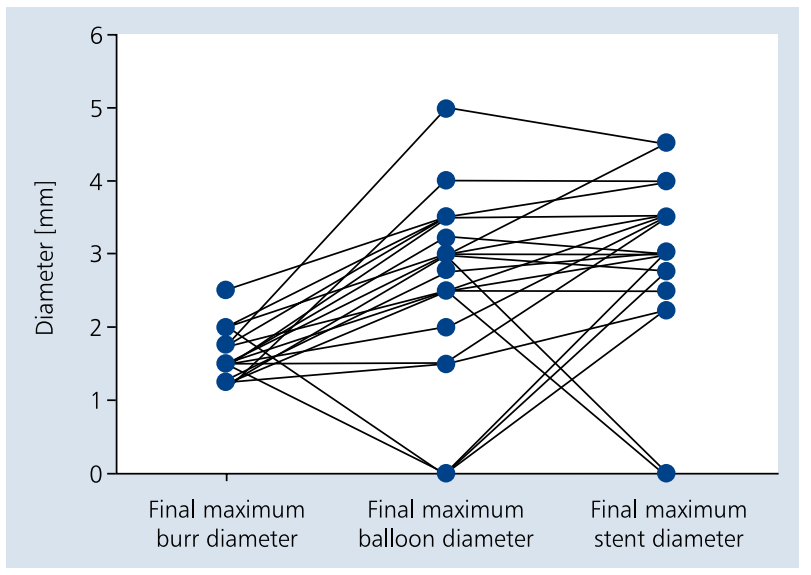

Figure 1. The relationship between final maximum burr diameter, final maximum balloon diameter used after rotablation, and final maximum diameter of implanted stent

of cases and $\mathrm{C}$ in $78.3 \%$. PCl was assisted with an intravascular ultrasound device (Eagle Eye ${ }^{\circledast}$ Platinum Catheter, Volcano) in $15(25 \%)$ patients and with optical coherence tomography in two $(3.3 \%)$ patients. A single $1.25-\mathrm{mm}$ burr was used in $12(20 \%)$ patients, $1.5-\mathrm{mm}$ in $32(53.3 \%), 1.75-\mathrm{mm}$ in eight (13.3\%), 2.0-mm in three (5\%) patients, and $2.5-\mathrm{mm}$ in one (1.7\%) patient. In two (3.3\%) cases, a 1.25-mm burr size was used initially with progression to a $1.5-\mathrm{mm}$ burr. In one case, it was necessary to replace the primary $1.25-\mathrm{mm}$ burr with a $1.75-\mathrm{mm}$ burr $(1.7 \%)$, and in another one, the primary $1.25-\mathrm{mm}$ burr was replaced with a $1.5-\mathrm{mm}$, and finally with a 1.75-mm burr, which led to successful RA (1.7\%). The mean burr size was $1.53 \pm 0.23 \mathrm{~mm}$. The mean contrast volume used for the procedure including coronary angiography prior to the procedure was $283.6 \pm 106.6 \mathrm{~mL}$, and mean radiation exposure was revealed at $2.16 \pm 1.16$ Gy. We noticed periprocedural complications in $12(20 \%)$ patients. Among them, coronary artery dissection occurred in one patient, cardiogenic shock followed by death in two patients, cardiogenic shock with hypotonia demanding inotropes and vasopressors in one patient, periprocedural $\mathrm{Ml}$ in two cases, local haematoma demanding blood transfusion in one case, guidewire cutting and pericardial contrast extravasation in one case, slow-flow phenomenon and bradycardia in one case, contrast nephropathy in one patient, perforation of femoral artery with extraperitoneal haematoma demanding surgical supply in one case, and supraventricular tachycardia treated with intravenous antiarrhythmic drugs in one case. The relationship between ischaemic complications during the RA procedure and clinical presentation of coronary artery disease is demonstrated in Table 3. Based on retrospective observations, slow-flow and no-reflow phenomenon tend to occur after RA in patients with acute coronary syndromes, especially STEMI, where the risk soft thrombotic lesions is substantially higher. The risk of embolisation of the peripheral

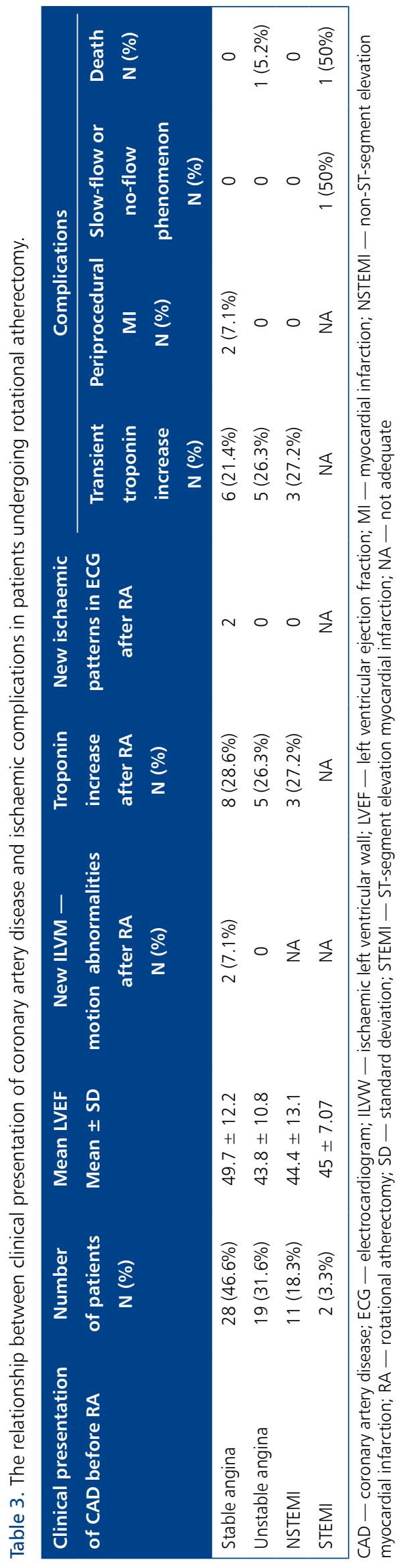




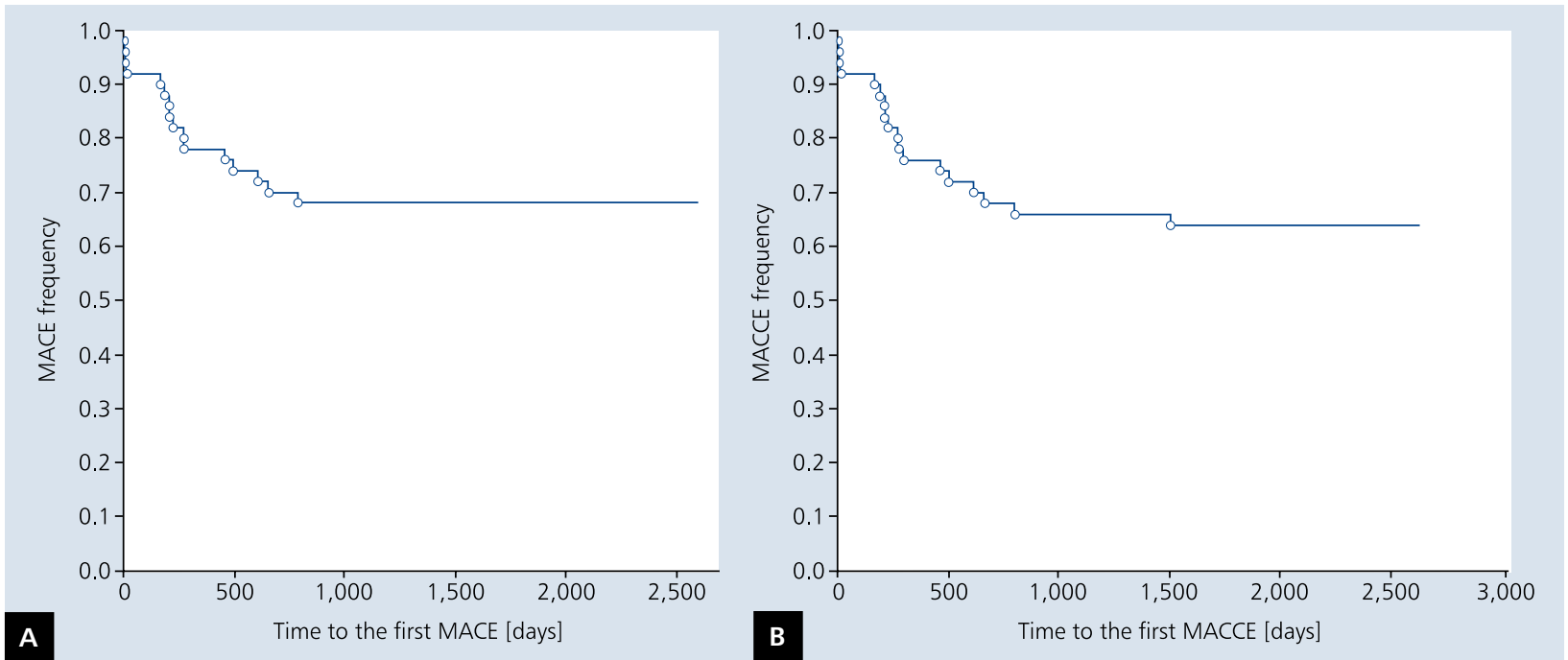

Figure 2. The Kaplan-Maier curves of major adverse cardiovascular events (MACE) (A) and cardiovascular and cerebrovascular events (MACCE) (B)

arteries in patients with stable angina and potentially more dense embolic material seems to be firmly lower.

Follow-ups were conducted in 50 (83.3\%) patients after the RA. The Kaplan-Maier curve revealed $64 \%$ patients free of MACCE and 68\% free of MACE after the maximal 2,616 days of observation (Fig. 2). The mean time of the follow-up period was $835.3 \pm 611.8$ days. During follow-up, there were six deaths, including two periprocedural deaths, eight TLRs, four cerebral strokes, and four Mls. Univariate Cox analysis revealed that MACCE occurred significantly more often in patients from the high-risk group assessed before the RA by the EuroSCORE II (Table 4). Also, longer length of the implanted stent(s) after the RA procedure was related to lower MACCE occurrence (Table 4). In multivariate Cox regression analysis, both high-risk category based on EuroSCORE II (HR 5.53; 95\% Cl 1.78-17.23; $\mathrm{p}=0.003)$ and mean stent(s) length (HR [95\% Cl] high-risk vs. other: 0.89 [0.81-0.98]; $\mathrm{p}=0.013$ ) were identified as independent predictors of MACCE. Similarly, EuroSCORE II was confirmed to be the only independent predictor of MACE after RA (HR [95\% Cl] per 1\%: 1.08 [1.03-1.13]; $p<0.001$ ).

\section{DISCUSSION}

In the current study, all RA procedures were effective from the technical side and were completed with successful PCl. However, this did not allow avoidance of severe complications, such as the death of the patient in two cases. Almost $90 \%$ of RAs were performed with 1.25- and 1.5-mm single burr passages. This confirms the presently observed trends that usually, a few passages with single burr diameter (most often $1.5 \mathrm{~mm}$ in diameter) are sufficient to continue successful PCl with stent implantation [2]. It is suggested that a single 1.5-mm burr represents a good compromise when tackling different lesion characteristics and achieves good plaque modification. A different strategy is the burr-to-artery ratio of 0.6. It is justified especially when considering budget constraints. However, a step-up approach starting with a $1.25-\mathrm{mm}$ burr up to a $1.5-\mathrm{mm}$ and to a $1.75-\mathrm{mm}$ burr is deemed by experts to be a safer approach [2]. Although, this approach is more expensive. High rotational speeds facilitate longitudinal burr movement across calcific lesions [2]. The most common complications of RA are similar to those that can be observed in patients after regular $\mathrm{PCl}$, and they include vascular access complications, stroke, MI, urgent $\mathrm{CABG}$, and death. In the current study, severe local bleeding from the artery puncture site occurred in one patient. The rise in the frequency of radial artery access in the present study remains in line with international trends and is determined by relatively safe access of 6 and 7 French sheaths for 1.25- and 1.5-mm burr sizes. Angiographic complications include artery dissection, perforation, short-term closure, side branch loss, and the slow-flow or no-reflow phenomenon [2]. Complications, especially attributed to RA, include vasospasm and burr entrapment. Plaque modification during RA decreases the likelihood of procedural failure, stent under-deployment, restenosis, and major complications. Retrospective studies present high rates of short-term procedural success in patients undergoing RA. They range from $93.4 \%$ to $98.6 \%$ and do not deviate from our results. For example, Moussa et al. [3] reported procedural success in $93.4 \%$ of individuals. Periprocedural success rates are superior in patients with RA compared to those reported separately in the absence of plaque modification. Coronary lesions with CAC are classified as complex lesions and carry lower success rates and higher complication rates 
Table 4. Univariate analysis of factors influencing the incidence of major adverse cardiac events (MACE) and major cardiac and cerebrovascular events (MACCE) after rotational atherectomy procedure

\begin{tabular}{|c|c|c|c|c|}
\hline & MACCE - HR $(95 \% \mathrm{Cl})$ & $\mathbf{P}$ & MACE - HR $(95 \% \mathrm{Cl})$ & $\mathbf{P}$ \\
\hline Gender (male/female) & $0.58(0.22-1.54)$ & 0.28 & $0.66(0.23-1.91)$ & 0.45 \\
\hline Access (femoral/radial) & $0.78(0.22-2.76)$ & 0.70 & $0.64(0.18-2.34)$ & 0.50 \\
\hline IVUS control (yes/no) & $0.83(0.28-2.54)$ & 0.75 & $0.99(0.32-3.07)$ & 0.99 \\
\hline Past CABG (yes/no) & $2.40(0.90,6.42)$ & 0.08 & $1.51(0.49-4.68)$ & 0.48 \\
\hline Past PCI (yes/no) & $0.59(0.23-1.51)$ & 0.27 & $0.65(0.24-1.79)$ & 0.41 \\
\hline Diabetes mellitus (yes/no) & $1.55(0.60-4.00)$ & 0.37 & $1.67(0.61-4.60)$ & 0.32 \\
\hline Insulinotherapy (yes/no) & $2.0(0.78-5.16)$ & 0.15 & $1.90(0.69-5.23)$ & 0.21 \\
\hline Peripheral arterial disease (yes/no) & $1.02(0.36-2.86)$ & 0.97 & $1.21(0.42-3.49)$ & 0.72 \\
\hline Cerebral stroke/TIA (yes/no) & $0.89(0.26-3.07)$ & 0.85 & $1.05(0.30-3.67)$ & 0.95 \\
\hline Atrial fibrillation (yes/no) & $1.71(0.67-4.34)$ & 0.26 & $1.60(0.59-4.29)$ & 0.35 \\
\hline COPD (yes/no) & $0.56(0.13-2.44)$ & 0.44 & $0.65(0.15-2.86)$ & 0.57 \\
\hline Heart failure (yes/no) & $0.81(0.30-2.15)$ & 0.67 & $0.75(0.26-2.17)$ & 0.60 \\
\hline Antiplatelet therapy (DAPT and OAC vs. DAPT) & $1.73(0.67-4.48)$ & 0.26 & $1.55(0.56-4.28)$ & 0.40 \\
\hline Age (per 10 years) & $0.99(0.60-1.63)$ & 0.96 & $0.93(0.55-1.57)$ & 0.78 \\
\hline Mean stent diameter (per $1 \mathrm{~mm}$ ) & $1.16(0.53-2.56)$ & 0.72 & $1.04(0.45-2.41)$ & 0.94 \\
\hline Mean stent length (per $1 \mathrm{~mm}$ ) & $0.92(0.86-0.99)$ & 0.034 & $0.94(0.87-1.01)$ & 0.09 \\
\hline Maximal burr size (per $1 \mathrm{~mm}$ ) & $1.71(0.50-5.92)$ & 0.40 & $5.24(0.69-39.73)$ & 0.11 \\
\hline Contrast volume (per $100 \mathrm{~mL}$ ) & $1.44(0.93-2.23)$ & 0.10 & $1.52(0.98-2.35)$ & 0.06 \\
\hline LVEF (per 1\%) & $1.00(0.96-1.05)$ & 0.92 & $1.00(0.95-1.04)$ & 0.80 \\
\hline Radiation dose (per 1 Gy) & $1.39(0.95-2.03)$ & 0.09 & $1.50(1.01-2.21)$ & 0.043 \\
\hline Serum creatinine level (per $10 \mu \mathrm{mol} / \mathrm{L}$ ) & $1.08(0.98-1.19)$ & 0.13 & $1.08(0.98-1.19)$ & 0.12 \\
\hline GFR (per $1 \mathrm{~mL} / \mathrm{min}$ ) & $0.99(0.97-1.01)$ & 0.41 & $0.99(0.97-1.01)$ & 0.53 \\
\hline SYNTAX score (per 1 point) & $1.03(1.00-1.07)$ & 0.10 & $1.03(0.99-1.06)$ & 0.18 \\
\hline EuroSCORE II (per 1\%) & $1.09(1.04-1.15)$ & $<0.001$ & $1.08(1.03-1.13)$ & $<0.001$ \\
\hline Rotablated artery (RCA/other) & $0.28(0.06-1.22)$ & 0.09 & $0.33(0.08-1.45)$ & 0.14 \\
\hline Number of stents (per 1 stent) & $0.99(0.53-1.85)$ & 0.98 & $1.13(0.60-2.11)$ & 0.71 \\
\hline Procedure mode (elective vs. other) & $0.52(0.19-1.37)$ & 0.18 & $0.48(0.17-1.39)$ & 0.18 \\
\hline Risk group according to SYNTAX score (high risk vs. other) & $1.07(0.40-2.85)$ & 0.90 & $0.95(0.33-2.72)$ & 0.92 \\
\hline Risk group according to EuroSCORE II (high risk vs. other) & $2.66(1.03-6.89)$ & 0.044 & $2.34(0.85-6.44)$ & 0.10 \\
\hline
\end{tabular}

CABG — coronary artery bypass grafting; Cl — confidence interval; COPD — chronic obstructive pulmonary disease; DAPT — dual antiplatelet therapy; GFR — glomerular filtration rate; HR — hazard ratio; IVUS — intravascular ultrasound; LVEF — left ventricular ejection fraction; OAC — oral anticoagulation; $\mathrm{PCl}$ — percutaneous coronary intervention; RCA — right coronary artery; TIA — transient ischaemic attack

following PCl than do non-calcified or mildly calcified lesions $[5,9]$. In the current study, the percentage of complex lesions with advanced calcifications was high (78.3\% of type $\mathrm{C}$ and $21.7 \%$ of type B) and comparable with other studies. Advanced CAC also poses technical challenges during $\mathrm{PCI}$ resulting in stent under-expansion, malposition, or the inability to place a stent [8]. Extensive CAC may damage the polymer coating of DES and contribute to decreased DES effectiveness [10]. Treatment of challenging calcified lesions often leads to increased MACE rates. The ORBIT II trial reported the successful stent delivery in $97.7 \%$ of the included patients and residual stenosis $<50 \%$ in $98.6 \%$ with a low angiographic complication rate $[11,12]$. The incidence of slow-flow and no-reflow was notably very low, occurring in $<1 \%$ of patients. In contrast, Japanese studies on RA show a range of $0 \%$ to $18 \%$ [13]. In our study, we also noticed one patient with the slow-flow phenomenon. In previously published studies, the percentage of advanced dissections have ranged from $2.1 \%$ to $8.4 \%$ [14]. We observed one coronary artery dissection and one coronary artery perforation due to guidewire cutting. Perforation rates of $0 \%$ to $1.5 \%$ have been reported with high-speed RA, and they differ based on technique [15]. The ORBIT II trial had among the lowest rates of this complication [11]. Similarly, abrupt closure occurred in 
$0.9 \%$ of individuals after the use of $\mathrm{OA}$, and in $1.8 \%$, after the procedure, compared with rates from $1 \%$ to $4 \%$ from other studies that reported abrupt closure during RA [11, 12]. Perforations occurred in $0.9 \%$ of patients after the use of OA and in $1.8 \%$ after the procedure, compared with $0.4 \%$ to $2.5 \%$ in RA studies reporting on this complication [15]. The perforation rate after OA use is in the low end of the previously reported range, and the final ORBIT II perforation rate is within the range. Despite these successes, other reports suggest that distal embolisation of atherectomy fragments may result in slow-flow or no-reflow, which can result in serious complications such as adverse ischaemic and clinical events including, but not limited to, microvascular spasm, MI, and no-reflow phenomenon [16, 17]. RA has been proven to be superior to other atherectomy devices with respect to plaque modification. In the ERBAC study, RA had the greatest initial success percentage: $89 \%$ vs. $77 \%$ in the EL group and vs. $80 \%$ in balloon angioplasty (BA) group. No differences were observed regarding major in-hospital complications and after six months [18]. TLR was performed more frequently in the RA group (42.4\%) and the EL group (46.0\%) than in the BA group (31.9\%, $p=0.013$ ) [18]. In the COBRA trial, 502 patients were enrolled and similar results were achieved [19]. The procedural success was achieved in $78 \%$ of individuals from the $\mathrm{PCl}$ group, and in $85 \%$ of the RA group $(\mathrm{p}=0.038)$. There was no difference between $\mathrm{PCl}$ and $\mathrm{RA}$ in periprocedural complications including Q-wave infarctions (2.4\% each), emergency CABG $(1.2 \%$ and $2.4 \%)$, and death $(1.6 \%$ and $0.4 \%)$. However, more stents were required after regular $\mathrm{PCI}$ in comparison to $\mathrm{PCl}$ with $\mathrm{RA}$. The procedural success rates after inclusion of the bail-out stents were $73 \%$ for angioplasty and $84 \%$ for RA ( $p=0.006)$. After six months of follow-ups, the symptomatic outcome, TLR, and in-stent restenosis were not statistically different in the $\mathrm{PCl}$ group $(51 \%)$ or RA group (49\%) [20]. Most published studies demonstrate better long-term effects of RA with DES than DES alone in terms of MACE and MACCE. The ROTAXUS survey included 240 patients with moderately or severely calcified obstructive lesions treated with or without RA before paclitaxel-eluting stent implantation and brought about different conclusions [8]. Greater strategic success and short-term lumen gain were noticed in the RA group. However, angiographic follow-up at nine months showed no difference in MACE and greater late lumen loss. In the ROTAXUS study, the MACE rate for calcified lesions treated with RA and DES was approximately $24 \%$ at nine months. In the current study, relatively high procedural and 30-day MACE rate were determined mainly by two deaths during the RA procedure. It is noteworthy that those two deaths occurred in extremely high-risk patients who were qualified for angioplasty as a salvage procedure. The first patient underwent RA of the left main coronary artery (LMCA) and additionally suffered from severe aortic stenosis. Moreover, this patient's EuroSCORE II value of was $56 \%$ and SYNTAX score was 45 points. Parallel to RA, balloon aortic valvuloplasty was performed. The second patient underwent RA of the left anterior descending artery, which was additionally occluded by a thrombus, with STEMI and salvage mode, his EuroSCORE II value was $74.7 \%$ and SYNTAX score was 30.5 points. The RA procedure was performed in this patient despite the presence of contraindication - thrombus. However, after thrombectomy, it was not possible to perform effective $\mathrm{PCl}$ or deliver the stent due to advanced CAC. PCI using RA for LMCA lesions was reported to be feasible despite the high hospital mortality rate $(7.5 \%)$, which is comparable to that seen in our study [20]. In the present study, the in-hospital mortality rate was $3.8 \%$ and the 30 -day mortality rate was $3.8 \%$. Patients with severe CCAL are at very high risk and have poor prognosis in the short- and medium-term follow-up. In the current study, the cardiac mortality rate the one-year of follow-up was $5.7 \%$, which is considered acceptable because our study population had severely calcified lesions, high SYNTAX scores, and high EuroSCOREs. The flattening of MACE and MACCE curves after four years of follow-ups is due to a decrease in the number of patients who have reached such a long observational period. Undoubtedly, this causes underestimation of the rate of MACE and MACCE in more distant years of follow-up. Provided that well-trained operators are available, RA may be used as a device of choice, even in less experienced low-volume centres. Additionally, stent technology has improved and it is difficult to estimate the influence that the current technique would have on the results of this study. RA may be the only alternative to surgery for lesions that are resistant to high balloon pressures or when balloon delivery is not possible due to severe CAC. The introduction of the RotaLink system with interchangeable burrs leads to a considerable reduction in costs compared to inseparably linked disposable devices with one burr size. Further studies are necessary to clarify the role of RA combined with stents.

In the current study, we noticed that the high-risk group assessed by EuroSCOREs and shorter stent(s) deployed after RA were significantly associated with the incidence of MACCE, but not MACE.

\section{Limitations of the study}

The primary limitations of the present study are the small cohort of patients, the lack of randomisation, and the lack of a CABG arm. The overall number of events was low, thus the results from Cox regression analyses should be considered rather exploratory and hypothesis-generating.

\section{CONCLUSIONS}

In conclusion, RA is a safe and sufficient technique for endovascular treatment of severe CCALs, and in the hands of an expert, it may maintain its advantage over routine angioplasty with DES implantation even in high-volume centres with a low 
rate of RA procedures. Future long-term outcome studies are needed to evaluate the optimal technique for RA use, to determine whether routine use of RA before current-generation DES improves outcomes in high-risk patients with CAC, and whether those results are better than those seen in patients treated with cardiac surgery. Interventional cardiologists in high-volume centres should be familiar with RA and apply it more frequently in this specific group of patients.

\section{Conflict of interest: none declared}

\section{References}

1. Ritchie JL, Hansen DD, Intlekofer MJ, et al. Rotational approaches to atherectomy and thrombectomy. Z Kardiol. 1987; 76: 59-65, indexed in Pubmed: 3439260.

2. Barbato E, Carrié D, Dardas P, et al. European expert consensus on rotational atherectomy. EuroIntervention. 2015; 11(1): 30-36, doi: 10.4244/EIJV11I1A6, indexed in Pubmed: 25982648.

3. Moussa I, Di Mario C, Moses J, et al. Coronary stenting after rotational atherectomy in calcified and complex lesions. Angiographic and clinical follow-up results. Circulation. 1997; 96(1): 128-136, indexed in Pubmed: 9236427.

4. Benezet J, Díaz de la Llera LS, Cubero JM, et al. Drug-eluting stents following rotational atherectomy for heavily calcified coronary lesions: long-term clinical outcomes. J Invasive Cardiol. 2011; 23(1): 28-32, indexed in Pubmed: 21183767.

5. Clavijo LC, Steinberg DH, Torguson R, et al. Sirolimus-eluting stents and calcified coronary lesions: clinical outcomes of patients treated with and without rotational atherectomy. Catheter Cardiovasc Interv. 2006; 68(6): 873-878, doi: 10.1002/ccd.20615, indexed in Pubmed: 17086529.

6. Mangiacapra F, Heyndrickx GR, Puymirat E, et al. Comparison of drug-eluting versus bare-metal stents after rotational atherectomy for the treatment of calcified coronary lesions. Int J Cardiol. 2012; 154(3): 373-376, doi: 10.1016/j.ijcard.2011.11.048, indexed in Pubmed: 22197116.

7. Rathore S, Matsuo H, Terashima M, et al. Rotational atherectomy for fibro-calcific coronary artery disease in drug eluting stent era: procedural outcomes and angiographic follow-up results. Catheter Cardiovasc Interv. 2010; 75(6): 919-927, doi: 10.1002/ccd.22437, indexed in Pubmed: 20432398.

8. Abdel-Wahab M, Richardt G, Joachim Büttner H, et al. High-speed rotational atherectomy before paclitaxel-eluting stent implantation in complex calcified coronary lesions: the randomized ROTAXUS (Rotational Atherectomy Prior to Taxus Stent Treatment for Complex Native Coronary Artery Disease) trial. JACC Cardiovasc Interv. 2013; 6(1): 10-19, doi: 10.1016/j.jcin.2012.07.017, indexed in Pubmed: 23266232.

9. Généreux P, Madhavan MV, Mintz GS, et al. Ischemic outcomes after coronary intervention of calcified vessels in acute coronary syndromes. Pooled analysis from the HORIZONS-AMI (Harmonizing Outcomes With Revascularization and Stents in Acute Myocardial Infarction) and ACUITY (Acute Catheterization and Urgent Intervention Triage Strategy) TRIALS. J Am Coll Cardiol.
2014; 63(18): 1845-1854, doi: 10.1016/j.jacc.2014.01.034, indexed in Pubmed: 24561145.

10. Khattab AA, Otto A, Hochadel M, et al. Drug-eluting stents versus bare metal stents following rotational atherectomy for heavily calcified coronary lesions: late angiographic and clinical follow-up results. J Interv Cardiol. 2007; 20(2): 100-106, doi: 10.1111/j.1540-8183.2007.00243.x, indexed in Pubmed: 17391217.

11. Généreux P, Lee AC, Kim CY, et al. Orbital Atherectomy for Treating De Novo Severely Calcified Coronary Narrowing (1-Year Results from the Pivotal ORBIT II Trial). Am J Cardiol. 2015; 115(12): 1685-1690, doi: 10.1016/j.amjcard.2015.03.009, indexed in Pubmed: 25910525.

12. Bhatt P, Parikh P, Patel A, et al. Long-term safety and performance of the orbital atherectomy system for treating calcified coronary artery lesions: 5-Year follow-up in the ORBIT I trial. Cardiovasc Revasc Med. 2015; 16(4): 213-216, doi: 10.1016/j. carrev.2015.03.007, indexed in Pubmed: 25866032.

13. Tsubokawa A, Ueda K, Sakamoto H, et al. Acute and long-term outcomes of rotational atherectomy in small $(<3.0 \mathrm{~mm})$ coronary arteries. J Interv Cardiol. 2003; 16(4): 315-322, indexed in Pubmed: 14562671.

14. Mauri L, Reisman M, Buchbinder M, et al. Comparison of rotational atherectomy with conventional balloon angioplasty in the prevention of restenosis of small coronary arteries: results of the Dilatation vs Ablation Revascularization Trial Targeting Restenosis (DART). Am Heart J. 2003; 145(5): 847-854, doi: 10.1016/S00028703(03)00080-2, indexed in Pubmed: 12766743.

15. Kini A, Marmur JD, Duvvuri S, et al. Rotational atherectomy: improved procedural outcome with evolution of technique and equipment. Single-center results of first 1,000 patients. Catheter Cardiovasc Interv. 1999; 46(3): 305-311, doi: 10.1002/(SICI)152 2-726X(199903)46:3<305::AID-CCD9>3.0.CO;2-U, indexed in Pubmed: 10348127.

16. Kereiakes DJ, Turco MA, Breall J, et al. AMEthyst Study Investigators. A novel filter-based distal embolic protection device for percutaneous intervention of saphenous vein graft lesions: results of the AMEthyst randomized controlled trial. JACC Cardiovasc Interv. 2008; 1(3): 248-257, doi: 10.1016/j.jcin.2008.03.009, indexed in Pubmed: 19463308.

17. Sulimov DS, Abdel-Wahab M, Toelg R, et al. Stuck rotablator: the nightmare of rotational atherectomy. EuroIntervention. 2013; 9(2): 251-258, doi: 10.4244/EIJV9I2A41, indexed in Pubmed: 23793010

18. Reifart N, Vandormael M, Krajcar M, et al. Randomized comparison of angioplasty of complex coronary lesions at a single center. Excimer Laser, Rotational Atherectomy, and Balloon Angioplasty Comparison (ERBAC) Study. Circulation. 1997; 96(1): 91-98, indexed in Pubmed: 9236422.

19. Dill T, Dietz U, Hamm CW, et al. A randomized comparison of balloon angioplasty versus rotational atherectomy in complex coronary lesions (COBRA study). Eur Heart J. 2000; 21(21): 1759-1766, doi: 10.1053/euhj.2000.2242, indexed in Pubmed: 11052840.

20. Yabushita H, Takagi K, Tahara S, et al. Impact of rotational atherectomy on heavily calcified, unprotected left main disease. Circ J. 2014; 78(8): 1867-1872, indexed in Pubmed: 24920410.

Cite this article as: Bartuś S, Januszek R, Legutko J, et al. Long-term effects of rotational atherectomy in patients with heavy calcified coronary artery lesions: a single-centre experience. Kardiol Pol. 2017; 75(6): 564-572, doi: 10.5603/KP.a2017.0042. 


\title{
Długoterminowe wyniki zastosowania aterektomii rotacyjnej $u$ chorych $z$ silnie uwapnionymi zmianami miażdżycowymi w tętnicach wieńcowych: doświadczenia jednego ośrodka
}

\author{
Stanisław Bartuś ${ }^{1,2}$, Rafał Januszek1 ${ }^{1}$, Jacek Legutko ${ }^{1,2}$, tukasz Rzeszutko ${ }^{1}$, Artur Dziewierz ${ }^{1,2}$, Dariusz Dudek 1, 2, 3 \\ ${ }^{1}$ Il Oddział Kliniczny Kardiologii oraz Interwencji Sercowo-Naczyniowych, Szpital Uniwersytecki, Kraków \\ 2II Oddział Kliniczny Kardiologii, Uniwersytet Jagielloński, Collegium Medicum, Kraków \\ ${ }^{3}$ Oddział Kardiologii Interwencyjnej, Uniwersytet Jagielloński, Collegium Medicum, Kraków
}

\section{Streszczenie}

Wstęp: Aterektomia rotacyjna (AR) odgrywa ważną rolę w dobie szerokiego dostępu do zabiegów przezskórnych interwencji sercowo-naczyniowych (CV), szczególnie w erze starzenia się populacji i ekspansji wskazań do poszczególnych metod przezskórnych zabiegów w obrębie tętnic wieńcowych. Ograniczenia dla klasycznych przezskórnych interwencji wieńcowych z implantacją stentu uwarunkowane silnym uwapnieniem tętnic wieńcowych, często występujące u chorych w podeszłym wieku, obciążonych dużym operacyjnym ryzykiem CV, mają kluczowe znaczenie w powiększającej się grupie pacjentów poddawanych zabiegom RA. Cel: W niniejszym badaniu retrospektywnym oceniono częstość powikłań okołozabiegowych i długoterminowe efekty zastosowania AR. Dodatkowo przeanalizowano związek potencjalnych czynników ryzyka RA, które mogą wpływać na częstość występowania głównych incydentów sercowo-naczyniowych (MACE) oraz sercowo-naczyniowych i mózgowych (MACCE) w długoterminowym okresie obserwacyjnym.

Metody: Badaniem objęto 60 kolejnych chorych poddanych AR między styczniem 2002 r. i majem 2016 r. Maksymalny okres obserwacji wynosił 2616 dni dla MACE (zgon, zawał serca i ponowna rewaskularyzacja naczynia docelowego) oraz MACCE (MACE i udar mózgu).

Wyniki: Średni wiek pacjentów objętych badaniem wynosił 72,1 roku; mężczyźni stanowili 78,3\% wszystkich chorych objętych badaniem. Średni odsetek EuroSCORE II wyniósł 6,5\%, natomiast SYNTAX score 24,1 pkt. Średni okres obserwacji trwał 835,3 $\pm 611,8$ dnia. Wszyscy chorzy przebyli skuteczny zabieg AR, a powikłania pozabiegowe wystąpiły u 12 (20\%) osób i były to m.in.: wstrząs kardiogenny u 3 chorych (z których 2 pacjentów zmarło), rozwarstwienie tętnicy wieńcowej u 1 chorego, okołoabiegowy zawał serca u 2 chorych, a także krwiak związany z dostępem naczyniowym wymagający przetoczenia koncentratu krwinek czerwonych, przerwanie ciągłości prowadnika, nadkomorowe tachykardia leczona parenteralnymi lekami antyarytmicznymi, perforacja tętnicy udowej powikłana krwiakiem pozaotrzewnowym wymagająca zaopatrzenia chirurgicznego, nefropatia kontrastowa oraz zwolniony przepływ kontrast w tętnicy poddawanej zabiegowi AR, odpowiednio, u 1 pacjenta. W okresie obserwacyjnym, który maksymalnie wyniósł 2616 dni, 64\% chorych było wolnych od MACCE, natomiast $68 \%$ od MACE. Analiza jednoczynnikowa Coxa wykazała większą częstość występowania MACCE w grupie osób z większym ryzykiem CV oszacowanym za pomocą skali EuroSCORE II przed zabiegiem oraz z większą długością implantowanych stentów. W przypadku MACE taki związek wykazano jedynie dla odsetka EuroSCORE II. W analizie wieloczynnikowej metodą Coxa, zarówno średnia długość stentu, jak i EuroSCORE II były niezależnymi czynnikami ryzyka wystąpienia MACCE w grupie chorych po RA, natomiast w przypadku MACE niezależnym czynnikiem okazał się tylko EuroSCORE II.

Wnioski: Aterektomia rotacyjna jest bezpieczną i skuteczną metodą leczenia wewnątrznaczyniowego w grupie chorych z masywnymi zwapnieniami w tętnicach wieńcowych. W badanej populacji pacjentów po kolejnych zabiegach AR przeprowadzonych w ciągu kilkunastu lat, wykonanych w jednym ośrodku, większe ryzyko CV w skali EuroSCORE II przed zabiegiem AR oraz większa średnia długość implantowanych stentów po zabiegu AR okazały się czynnikami ryzyka związanymi z większą częstością wystąpienia MACE i MACCE w długookresowej obserwacji.

Słowa kluczowe: aterektomia rotacyjna, komplikacje, skuteczność, główne incydenty sercowo-naczyniowe oraz mózgowe

Kardiol Pol 2017; 75, 6: 564-572

\section{Adres do korespondencji:}

dr n. med. Rafał Januszek, II Oddział Kliniczny Kardiologii oraz Interwencji Sercowo-Naczyniowych, Szpital Uniwersytecki w Krakowie, ul. Kopernika 17, 31-501 Kraków, e-mail: jaanraf@interia.pl

Praca wpłynęła: 25.10.2016 r. Z Zaakceptowana do druku: 07.02.2017 r. $\quad$ Data publikacji AoP: 07.03.2017 r. 